\title{
Literature as a Medium for Social and Political Activism: The Case of Mashingaidze Gomo's A Fine Madness
}

\author{
Rodwell Makombe
}

\begin{abstract}
Over the years, literary scholars have engaged in heated debates on the role literary artists should play in society. In the African context, this debate has been championed by scholars such as Ngũgĩ wa Thiong'o, Chinua Achebe, and Okot p' Bitek, among others. The central bone of contention has always been the question of self-narration. How should African writers narrate the African story (-ies) against the backdrop of slavery, colonialism, and neoliberal imperialism? In the context of these debates, this article seeks to read A Fine Madness by the Zimbabwean writer Mashingaidze Gomo (2010) as a socially and politically engaged text.
\end{abstract}

Résumé: Au cours des années, les chercheurs littéraires se sont engagés dans des débats animés sur le rôle que les artistes littéraires devraient jouer dans la société. En Afrique, cette question a été débattue par des érudits tels que Ngũgĩ wa Thiong'o, Chinua Achebe et Okot p' Bitek, qui demandent, par exemple, comment les écrivains africains doivent raconter l'(les) histoire (s) africaine(s) dans le contexte de l'esclavage, le colonialisme et l'impérialisme néolibéral. Dans le cadre de ces débats, cet article cherche à lire A Fine Madness (2010) (Une bonne folie) de l'écrivain zimbabwéen Mashingaidze Gomo comme un texte socialement et politiquement engagé.

Keywords: Africa; nativism; Afropolitanism; soldier-narrator; Tinyarei

African Studies Review, Volume 60, Number 2 (September 2017), pp. 115-138

Rodwell Makombe is a senior lecturer in the Department of English Literary and Cultural Studies at the University of the Free State, South Africa. He has published articles on crime, violence, and resistance in postcolonial African literature. E-mail: Makomber@ufs.ac.za 


\section{Introduction}

This article critically analyzes Mashingaidze Gomo's 2010 poetic novel A Fine Madness in the context of recent scholarly debates on the question of African "self-narration." A Although there is abundant literature on this subject, this article is underpinned by notions of African "self-writing" as articulated by Achille Mbembe (2002, 2007), Binyavanga Wainaina (2006), and Emma Dabiri (2014). Most African scholars have seen literature as a weapon that can be used to fight the anticolonial struggle on the epistemic front. The Nigerian writer and pioneer scholar of African literature Chinua Achebe envisaged his role as that of a teacher with a responsibility to teach Africans that "their past—with all its imperfections-was not one long night of savagery from which the first Europeans acting on God's behalf delivered them" (1990[1988]:45). In Achebe's formulation, African writers have a responsibility to reconstitute an African identity that was eroded by slavery and colonialism. On the other hand, the Kenyan writer and political activist Ngũgĩ wa Thiong'o insists that the writer has to take a leading role in society's daily struggles against all forms of oppression. Clearly, both Achebe and Ngũgĩ suggest a clearly defined role for an African writer, which is to reclaim and reaffirm an African sense of selfhood. Mbembe (2002), however, has dismissed this notion of reclaiming a lost identity as "nativist" and essentialist. Thus, in place of these sorts of initiatives, Mbembe recommends an alternative mode of self-writing that he calls "Afropolitanism" - the embrace of a fluid identity that is not necessarily limited to color and geographical location.

The text that I analyze in this article, A Fine Madness by the Zimbabwean writer Mashingaidze Gomo, is contextually situated in the post-2000 Zimbabwean narrative tradition, which is preoccupied with interrogating the political and economic crisis in Zimbabwe. This interrogation takes place in the context of the ZANU-PF government's attempt to correct the imbalances of the colonial past through a controversial policy of land distribution without compensation. Unlike some Zimbabwean writers such as Chenjerai Hove and Valerie Tagwira, who have portrayed the government's initiative as retrogressive and opportunistic, Gomo places the Zimbabwean situation in a broader African context and interrogates the role of the former colonizers in Africa's current economic and political woes. A Fine Madness is a neonationalist counterdiscursive narrative that reflects on the economic and cultural politics of the neoliberal global order so as to make sense of the alleged endemic failure of African governments. Thus, while Mbembe (2007) advocates Afropolitanism as a way of being-in-the-world that refuses any form of victim identity, Gomo is preoccupied with interrogating a situation in Africa in which liberation movements are under siege from Western-sponsored opposition parties and terrorist groups. The Kenyan writer and activist Binyavanga Wainaina has similarly questioned the viability of Afropolitanism as a mode of African self-writing, arguing that it has become the marker of crude cultural commodification-a phenomenon 
increasingly "product driven," "design focused," and "potentially funded by the West" (quoted in Santana 2013). It is in the context of these viewpoints that this article seeks to read A Fine Madness as a socially and politically engaged text that does not only identify problems, but also seeks to provide solutions to these problems. The article has two objectives: to read A Fine Madness as a socially and politically engaged text, and to interrogate the text's ideological convictions.

Contemporary Zimbabwean literature demonstrates a discernible resistance thread which has revitalized debates on how African cultural and political regimes should resist what appear to be new forms of imperialism disguised as Western ideals such as the rule of law, human rights, open markets, and democracy. In an article entitled "Writing Back to Colonialism Again," Oliver Nyambi (2015) observes that there is, in Zimbabwe, a burgeoning body of counterdiscursive literature that seeks to engage with the country's complex political and cultural milieu. Although this literary discourse has been labeled "nativist" by Sabelo Ndlovu-Gatsheni (2007) and "patriotic" by Terence Ranger (quoted in Ndlovu-Gatsheni 2009), these categories cannot fully express the complexity of the issues at hand. In an article entitled "African Modes of Self-Writing," Mbembe (2002) identifies "Afro-radicalism" and "nativism" as two modes of self-writing that have characterized African discourses of resistance. Afro-radicalism, as conceptualized by Mbembe, "uses Marxist and nationalist categories to develop an imaginaire of culture and politics in which a manipulation of the rhetoric of autonomy, resistance, and emancipation serves as the sole criterion for determining the legitimacy of an authentic African discourse" (2002:240). In the Marxist fashion of portraying the worker as a perpetual victim of monopoly capital, Afro-radicalism claims the right to sovereignty and self-determination by projecting the African as a victim of slavery, colonialism, and other external oppressive forces. Thus, while Afro-radicalism promotes a cult of victimhood in which Africans blame the colonial past for all their political, cultural, and economic woes, nativism "promotes the idea of a unique African identity founded on membership of the black race" (Mbembe 2002:240). It celebrates the particularity of the African identity by affirming that Africans have unique traditions and customs that make them different and therefore deserving of sovereignty. Africans, according to this formulation, are supposed to redefine and carve a space for themselves in the world on the basis of this uniqueness. But according to Mbembe, Afro-radicalism and nativism, as modes of asserting sovereignty and self-determination, are by and large retrogressive because they repeat and affirm the same binary logic of colonial discourse. Nativism keeps Africans in a state of limbo in which slavery, colonialism, and imperialism perpetually predetermine and shape the present and the future of Africa. For Mbembe (2002:251), this "neurosis of victimization fosters a mode of thought that is at once xenophobic, racist, negative, and circular."

While Mbembe's ideas are constructive as far as they provoke a new way of rethinking African modes of self-writing against the backdrop of the 
colonial past, Mbembe seems to want to dismiss nativism without asking why it keeps resurfacing in African political and cultural discourses. If key nationalist ideologies are all permeated by nativism, Ndlovu-Gatsheni (2009:64) argues, it does not make sense to spend more effort in dismissing nativism as mere anti-racist racism, or as fatalistic populist millenarianism, than in interrogating it. Mbembe's notions of "African modes of self-writing" attempt to dismiss African counterdiscourses of resistance on the pretext that they contribute nothing new and merely resuscitate categories of colonial discourse such as black versus white, settler versus native. The nativist celebration of the uniqueness of the African race is thus seen as trapped in the dualistic and/or binary discourses of colonialism which were systematically developed by colonizers to justify slavery and colonialism. Echoing Mbembe's sentiments, Chielozona Eze (2014:236) argues that the issue with the ideology of nativism is that it does not have within itself the means to extend the vision of the world beyond the essentialist enclave of African pristine villages. In Mbembe's view, nativist and Afro-radical modes of self-writing have led to a dead end, and therefore there is a need to formulate alternative ways of "self-styling." Eze states, in line with Mbembe, that identity is no longer shaped exclusively by geography or blood, or culture as understood in oppositional terms. African identities, as in most other parts of the world, are now shaped by elective affinities due to cultural and racial intermixing (2014:235).

While Mbembe dismisses nativism as retrogressive in African cultural politics, Benita Parry (1994) sees nativism as a reverse discourse with its own agency and status in the drama of decolonization. According to Parry, nativism need not always be associated with nationalism and overt racism. Remembering the past or invoking the colonial past is not necessary for the purposes of developing a culture of victimhood. The need to renew and activate memories is distinct from the uncritical attempt to conserve tradition. Invoking Edouard Glissant's metaphor of the Acoma tree-which should be remembered, although it has disappeared from the forest-Parry (1994:174) "urges a postcolonial construction of the past that is an imaginative reworking of the process of metissage or an infinitive wandering across cultures including those of Africa." Perhaps the question is: what does it actually mean to remember the Acoma tree? And why should it be remembered? In the context of this study, the answer can be gleaned in the upsurge of counterdiscursive narratives in post-2000 Zimbabwe, narratives that seek to respond to postcolonial governance issues in Africa and the role of the West therein. The question that Gomo's A Fine Madness and other post-2000 Zimbabwean texts such as Nyaradzo Mtizira-Nondo's The Chimurenga Protocol (2008) seem to grapple with is how to chart the future of African cultural and political regimes in a global order in which the imbalances of the colonial past are still intact. One can argue alongside Mbembe (2002:263) that "the thematics of anti-imperialism are exhausted" and that Africa needs a new way of self-styling. One can also argue, along with Eze (2014:237), that "much has happened in the world since the conception of Africanness by 
Achebe and Peter Tosh" - "the Berlin Wall has fallen" and "apartheid is legally defunct" - therefore it is time for new ways of imagining Africanness. Indeed, a lot has changed since the fall of colonial administrations, but what should be recognized is that in spite of all these changes, the world is still very much divided along lines similar to those on which the colonial world was divided. Eze acknowledges that "as much as globalization has shrunk the world it has also increased the gap between the haves and the have-nots" and has also "indirectly encouraged fundamentalist thinking and behavior as people seek to protect their cultural heritage that is at the risk of being destroyed by external influences" (2014:237). These divisions are aptly dramatized in the polarized nature of post-2000 Zimbabwean cultural productions that have broadly been categorized as patriotic (anti-Western) and unpatriotic (pro-Western). The contrast between Mbembe and Parry, for example (in terms of their take on nativism), can also be read as exemplifying the divided nature of our world.

In view of the challenges associated with nativism as a mode of selfwriting, some scholars such as Taiye Selasi (2005) have redefined themselves as "Afropolitans," or Africans who are not necessarily defined by race or a fixed geographical location-“Africans of the world." One of the criticisms that has been leveled against this alternative model is that it is elitist and unrepresentative of the generality of the African people (mainly black) who have been kept on the fringes of globalization. This elitism is clearly evident in Selasi's definition of "Afropolitans": "You'll know us by our funny blend of London fashion, New York jargon, African ethics, and academic successes. Some of us are ethnic mixes, e.g. Ghanaian and Canadian, Nigerian and Swiss; others merely cultural mutts."

Perhaps the question is-how many Africans can afford the luxury of a funny blend of London fashion, New York jargon, and academic successes? Although Mbembe, who also embraces this concept as defined by Selasi, claims that Afropolitanism's denial of a victim identity does not mean that it is "not aware of the injustice and violence inflicted on the continent and its people by the law of the world" (2007:26), he does not tell us what should be done about this victimization. Responding to the Afropolitan call for fluid identities, Dabiri (2016:105) asks an important question: "In what way does Afropolitanism go about challenging the enduring problematics of duality and compartmentalized society identified by Fanon as one of the major stumbling blocks to African post-colonial independence?" Dabiri further asserts that "the danger of Afropolitanism becoming the voice of Africa can be likened to the criticisms leveled against second-wave feminists who failed to identify their privilege as white and middle class, while claiming to speak for all women" (2016:105). Can Africans really afford to ignore the victimization of international capital that continues to disenfranchise the majority? Can Africans in countries such as South Africa and Zimbabwe continue to ignore the racialized distribution of wealth? Afropolitanism seems to focus on the success stories of a few individuals (and these successes are often measured in terms of one's proximity to the Western metropolis) 
while ignoring the rest of Africans who have "almost absolute immobility in a contemporary global world that works very hard to keep Africans in their place on the African continent" (Ogbechi 2008, quoted in Dabiri 2016:106).

I agree with Dabiri's reservations about the glaring shortcomings of the ideals of Afropolitanism, particularly in a world that continually seeks to frog-trot and marshal Africans into a skewed global political and cultural market. The Zimbabwean cultural and political landscape since 2000 exemplifies a complex postcolonial reality that cannot be explained away by Afropolitan ideals of embracing fluidity and celebrating a "contaminated" African culture. As Nyambi (2015) acknowledges, in the post-2000 period the relationship between Zimbabwe and the former colonizer, Britain, has been more complex than the straightforward colonized victim and colonizer victimizer images evoked in "patriotic" narratives of contemporary Zimbabwe. Nativism, as Ndlovu-Gatsheni puts it, "has very deep foundations in objective economic, political, social and cultural processes," and it is therefore important to understand "contemporary social forces that produce nativism" (2007:19) rather than being carried away by the universalizing ideals of Afropolitanism.

While some scholars such as Eze (2014) tend to dismiss patriotic narratives as manifestations of nativism, I seek to interrogate these narratives in order to understand why they keep resurfacing in African countries. First, one has to recognize that these discourses develop within a particular context. In the case of Zimbabwe, the context includes, among other things, the West's perpetual desire to influence politics in Africa either directly (through regime change) or indirectly (through aid-with-strings-attached). Parry has cautioned that nativism need not necessarily be associated with nationalism and racism, for it has its own agency. The past is evoked not to affirm a neurosis of victimization, as Mbembe has suggested, but to point out a real problem that the majority of Africans have had to live with for centuries. The resurgence of nativist political and cultural discourses, as evidenced by the recent formation of the Economic Freedom Fighters (EFF) in South Africa, cannot be dismissed as fruitless antiracist racism. What gives currency to these discourses are realities (cultural, economic, and political) that obtain in the neoliberal global order. In Zimbabwe the nativist discourses of the ruling party are not limited to the "Africa for Africans" rhetoric but also apply to issues of unequal distribution of resources such as land and minerals. This is not to say that African regimes should be seen as helpless victims with no agency, but that meaningful agency cannot be attained in a situation where colonial structures are still firmly in place. In the meantime, the West continues to project a distorted "colonialist" image of Africa in Western media. Wainaina (2006) criticizes in particular the Western media's portrayal of Africa as the starving child and the West as the selfless aid donor. These depictions seek to exonerate Europe/America from any responsibility for the political and economic woes in Africa. Yes, Africa cannot blame Europe/America for all its problems. But it is hypocritical for the West to posture as superhero, saving Africa from itself, 
even as it continues to promote unfair economic and political practices. This hypocrisy is aptly captured by Wainaina in his ironic article "How to Write about Africa" (2006), in which he says that Africa continues to be portrayed as the uncivilized opposite of the West, as "the Starving African who wanders the refugee camp nearly naked, and waits for the benevolence of the West." Ironically, the West, which is implicated in Africa's political and economic woes, also doubles up as benefactor.

Mashingaidze Gomo's A Fine Madness illustrates this contradiction through the oxymoronic "fine madness" of the title. In a situation in which the oppressor claims to be working for the general good of the oppressed, it is difficult to determine what mode of self-narration is progressive. Is it the anticolonial rhetoric of the Mugabe regime or the pro-democracy rhetoric of the opposition? In the Zimbabwean political sphere it is difficult to define "the side of the people," because both state and oppositional discourses claim to be on "the side of the people" and seek to influence the nation's democratic agenda. While it is easy to dismiss the anti-imperialist discourses of the governing regime as a manifestation of nativism, the realities of the Zimbabwean landscape have shown that injustices of the colonial past cannot be ignored. Writing about the difficulty of distinguishing between versions of resistance narratives in Zimbabwe, Nyambi observes that it is difficult to differentiate the hegemonic "patriotic narrative" from the "emancipatory narratives" that oppose it:

\begin{abstract}
Patriotic literary narratives enter the public domain with their own meanings and perceptions and also aiming to gain "recognition" and "solidarity" in their own ways. The concomitant question is therefore: whose "recognition" and whose "solidarity," the answer to which should differentiate the "patriotic narrative" from what can be called the emancipatory "social" literary narratives. (2011:3)
\end{abstract}

In this passage Nyambi implies that the only way pro-establishment resistance narratives can be separated from anti-establishment resistance narratives is by looking at their intended target audience. In the Zimbabwean context, this formulation remains contentious because the patriotic (proestablishment) narrative seeks "recognition" from and "solidarity" of the masses, who, ideally, should be on the side of the emancipatory forces. While the masses may be attracted to the neoliberal discourse of the opposition, they are also, in the same breath, enticed by the redistributive justice of the ruling party. The question is: How do you separate the gift-bearer (the Mugabe regime) from the gift itself (land)? Do you throw away the baby with the bathwater? The theorist Maria Pia Lara argues that art is a form of "rationality, expressive rationality" and that when it goes into the public sphere it represents a form of rationality subject to different interpretations (quoted in Nyambi 2011:4). Thus, in the convoluted logic of the Zimbabwean narrative space, Gomo's A Fine Madness is a form of rationality that enters the public sphere as a force sympathetic to the state, advancing 
its rule and consequently subverting antigovernment voices. A Fine Madness can be read as a text that attempts to interrogate the anti-imperialist rhetoric of the Mugabe regime without uncritically dismissing it as another form of nativist madness.

\section{Context and Background}

Mashingaidze Gomo is a Zimbabwean writer and soldier who participated in the Mozambiquean civil war of the 1980s and the DRC war of 1998 following the fall of Mobutu's dictatorship. Born in Harare's Highfield Township in 1964, Gomo is the fourth in a family of eight. His father was a driver at one of Zimbabwe's most popular bakeries, Lobels, while his mother was a peasant farmer in Chihota village. Like most young Zimbabweans of his generation, Gomo spent the early years of his life in his parents' rural home. Although his mother was partially literate, having gone to school only up to Standard Three, she believed in education and thus became a source of inspiration to the young Mashingaidze. After completing his Advanced Level in Harare, Gomo joined the Air Force of Zimbabwe as an apprentice and worked there for almost twenty-three years (Gore 2012). During his years in the army, particularly the early years of independence, Gomo encountered racial attitudes from his white superiors who kept threatening him with dismissal. When the Mozambiquean civil war broke out in the late 1980s, Gomo was part of the Zimbabwean Army contingent that was deployed to assist the forces of the Mozambiquean regime. It was during this war that Gomo saw, first hand, "the Renamo bandits destroying critical infrastructure for national development from bridges and roads to buildings and electricity power lines" (quoted in Gore 2012). This brief survey of Gomo's life history resonates with life histories of many Zimbabweans-one starts off in the barren rural areas (originally designated as animal reserves by the colonial regime), then one moves to the city in an attempt to break the cycle of poverty, either through education or employment, and eventually (almost inevitably) one comes into contact with structural disenfranchisement, either due to the legacy of colonialism or as a result of postcolonial poor governance. Gomo, unlike most Zimbabweans, had a first-hand encounter with antiliberation forces in the Mozambiquean war, which, as it is widely known, was financed by the apartheid regime of South Africa. He was also actively involved in the DRC war of 1998 which was, by and large, a war over the country's vast mineral resources.

In A Fine Madness Gomo draws from his experiences of the horrors of war to reflect on wider issues of colonial exploitation and the possibilities of a pan-Africanist vision of the continent (Whittaker 2010). His narrative is authenticated by the fact that he gives the reader an insider's perspective into the experiences of a soldier in the Democratic Republic of Congo (DRC) war of 1998, which pitted combined African forces from the DRC, Zimbabwe, Angola, South Africa, and Namibia against Western-sponsored 
insurgents from the DRC, Rwanda, and Uganda (Ziwira 2015). Adopting an Afro-radical, anti-imperialist approach, Gomo represents governing regimes in Africa not as oppressors, but as victims of international capital and Western imperialism. Those that oppose postcolonial regimes (derogatorily labeled "rebels/terrorists") are portrayed as puppets who seek to further the neocolonial agenda of former colonial masters. The argument is that governing regimes in Africa cannot implement their people-oriented mandates because of the West's continued meddling in African affairs.

Whereas Mbembe has theorized regimes in the postcolony as a "commandement" (1992:3), or a system of government that rules by orders and commands, Gomo views African regimes as different, not because they have inherited the repressive machinery of the colonial administration, but because they operate within a particular neo-imperialist context. This is perhaps because of his first-hand experiences of war against foreign-sponsored rebel movements. It is also likely that Gomo sympathizes with the official discourse in Zimbabwe which portrays opposition groups such as MDC (Movement for Democratic Change) as puppets of the West that are being used to push an imperialist agenda. While Mbembe seems to portray postcolonial regimes as self-serving entities that seek to hoodwink the masses through empty rhetoric and prodigal displays of power, Gomo is actually on the side of African regimes that allegedly are being sabotaged by former colonial masters with the assistance of local opposition parties and rebel groups. While Gomo's ideas resonate with Fanon's claim that "the issue which blocks the horizon [today] is the need for a redistribution of wealth" (2004:55), he does not seem to share Ngũgĩ' wa Thiong'o's view of governing regimes in Africa as "a small class of native 'haves' which is tied to international monopoly capital” (1981:78-79). Instead, Gomo's equivalent of what Ngũgĩ calls "native haves" is what he calls the "African funeral men" (69), or foreign-sponsored opposition groups that are prepared to sell their birthright for a mess of pottage. The "African funeral men" (harbingers of death for Africa) work hand in hand with the West to destabilize "progressive" liberation movements that seek to right the wrongs of the past. Indeed, in his prophetic way, Fanon singled out the issue of the redistribution of wealth as one that "humanity will have to address no matter how devastating the consequences may be" (2004:55). Gomo's A Fine Madness can be read as an attempt to interrogate and rationalize, rather than condemn and dismiss, the redistributive justice of the Mugabe regime.

\section{The "Fine Madness" of A Fine Madness}

Mashingaidze Gomo's A Fine Madness is thus a socially and politically engaged text which does not only interrogate postcolonial challenges facing the African continent, but also proposes possible ways of addressing these challenges. Theorizing the reading of post-2000 Zimbabwean literature, Nyambi (2011:1, quoting Lara 1998) recommends a reading framework that conceptualizes literary works as "emancipatory narratives 
that create new forms of power and configure new ways to fight back against past and present injustices." In Lara's philosophy, art enters the public sphere to begin an inclusive process of societal renewal through extending the boundaries of the normative in the expressive sphere. "Emancipation" therefore entails (among other things) the recovery of inclusiveness and the consequent dismantling of the previous privileging of certain narratives in the shaping of the public sphere. In the Zimbabwean context, the notion of literature as "emancipatory" is not limited to the Marxist idea of liberating the oppressed from capitalist exploitation, but it extends to liberating Africans from colonial epistemologies that seek to keep them as subjects of Western thought. Storytelling, according to Lara's formulation, becomes a deliberate and purposeful remodeling of history, a task (and method) that has been successfully developed by feminists to influence gender and power relations in the public sphere. A Fine Madness can also be seen as a selfwriting project in which "to tell" is also "to un-tell."

In view of the above, A Fine Madness becomes a defiant text that refuses to be browbeaten into Western categories of what constitutes art. The text is, in fact, difficult to categorize in terms of its genre. Whittaker (2010) describes it as a "kaleidoscope of notes and fragmentary diary entries, poetry and prose, factual descriptions and phantasmagorical flights of fancy." Gomo himself sees the text as a novel because it has a plot, characters, and a theme. For the purposes of this article, it will be categorized as a poetic novel. The story is set in the Democratic Republic of Congo (DRC) where the soldier-narrator is participating in a raging war against rebels who seek to oust the government of Laurent Kabila. As Dabiri argues (2014:106), African self-writing should not only focus on the "narratives of a privileged few" but also the "voices of a majority who remain denied basic life chances." Postindependence African literature, as exemplified by the works of Ngũgĩ wa Thiong'o and Chinua Achebe, has been characterized by dystopia as it laments the manner in which the ruling elites have abandoned the objectives of the anticolonial struggle to pursue selfish interests.

A Fine Madness constitutes a new wave of counterdiscursive literature, particularly in Zimbabwe, which aims to problematize Africa's political and economic predicament in the context of the pressures of neoliberal globalization. The "fine madness" of the title is a radical deconstruction of the notion of "madness" as it is conceived by hegemonic cultures and knowledge systems in the West. To categorize someone as "mad" is to fix the individual in order to assert control. In his studies of the institutionalization of madness in Europe, Foucault demonstrated that "madness" was politically constructed to meet the demands of capitalism. The "mad" category was ascribed not to those with a medical problem, but to those "without resources, without social moorings, a class rejected or rendered mobile by new economic developments" (1988:47). The "mad" people who were rounded up and confined in European cities of the seventeenth century were not really mad as we know madness today. Most were simply poor, unemployed, and idle-a description that resonates with the condition of many Africans in 
the postcolony today. Similarly, the redistributive justice of the Mugabe regime ("a fine madness") has been widely popularized as madness in the Western media, yet this madness is meant to address real social injustices. Western epistemology has a tendency to dismiss the unfamiliar or the uncomfortable as "abnormal." Therefore, to say "madness" is "fine" is to challenge Western epistemic hegemony and affirm indigenous ways of knowing. To say "madness" is "fine" is to say there is nothing wrong with the way Africans do things, politically, socially, culturally, economically. Africa is simply a different landscape, informed by different knowledge frameworks. In this sense, A Fine Madness becomes a celebration of alternative, marginalized epistemologies which are often dismissed by dominant, usually Western, knowledge regimes as primordial.

The first chapter, entitled "Tinyarei (Give us a break)" affirms this point in an interesting way. Tinyarei is a Shona word that means "show us respect." This word is normally used in provocative situations when one party has deliberately and spitefully undermined or disrespected another. In the context of postcolonial relations between Africa and its former colonial masters, "tinyarei" is a curse word directed at former colonial masters who continue to undermine the sovereignty of independent African countries. The fact that the prose-poem is written in English while its title is in Shona implies that the target audience is an English-speaking readership, preferably white people in the West, who, in official political discourse have been constructed as imperialists who are unwilling to "give us a break." It also implies the affirmation, as opposed to the erasure, of the local in the global. Although "tinyarei" is a provocative and confrontational statement directed at Western countries, Tinyarei is also the name of the narrator's fiancée, "an older woman aged in beauty" (4). Ziwira (2015) argues that Tinyarei stands for Africa, the beautiful, rich, and valuable continent impoverished by avarice, deceit, and chicanery at the center of the hypocritical West. The narrator celebrates Africa (Tinyarei), his aged fiancée whom he characterizes in colloquial street language as "the perfect thing" (4). Celebrating an old woman's beauty is not common; it is a kind of "madness," a refusal by the narrator to accept Western standards of beauty. Thus, in a defiant, anti-Western stance, the narrator insists that "the madness of falling in love with her [Tinyarei/Africa] should owe no explanation to anyone. . . . / Not even a group of white journalists from a European fashion magazine" (5). In the modern neoliberal context, opinions of "white journalists from a European fashion magazine" constitute a standard against which the whole world measures itself. Since the days of colonialism, Africa has been subjected to Eurocentric standards; hence the narrator is taking a radical position by refusing to seek the opinion of white journalists on Tinyarei's beauty. Although falling in love with an older woman may appear as madness, the narrator sees his love for Tinyarei as a "very fine and enjoyable madness" (8) because it is home grown; it "owes no explanation to anyone" (5). The implication is that Africans ought to be epistemologically located in Africa and not measure themselves against standards prescribed 
by Europeans. The point is certainly not to essentialize Africa or put it in a global vacuum but to recognize that the West is not the center around which the world revolves.

The narrator makes it clear that Europeans have a vested interest in Africa, which explains why they want Tinyarei to be globalized so that she can have less leverage over her Western economic suitors. Western countries believe that "there cannot be too much power over the hearts of men in any woman's hands" (4); therefore, Tinyarei's beauty (natural resources) should be scattered or shared. The bottom line is that the West does not want Africa to know its worth-hence the negative publicity, which is meant to reduce Africa's bargaining power on the international market. The narrator remembers an experience that he had with a priest at Sunday school who wanted him to change his name from Muchineripi to Peter or Joel. The narrator refused to change his name because it signified his identity. Thus, he refuses to be a globe-trotting "cultural mutt" (Selasi 2015), and prefers to be a nativist (Parry 1994; Ndlovu-Gatsheni 2007) who articulates specific challenges that affect Africans. The soldier-narrator, in this instance, was made to feel that his African name is evil, and when he refused to change it, the priest thought he was mad. What is interesting, however, is that the priest's name, Father Dion, is actually derived from Dionysus, "the pagan Greek god of wine and fertility" (9). Dionysus was not a Christian but "a drunkard who always walked with a good supply of beers" (9). The priest represents the West, which hides behind humanitarian aid in order to exploit Africa's resources. The narrator's name, "Muchineripi," is important because it testifies to Africa's colonial and postcolonial experiences. The narrator refers to his name as a "social statement" and a "slap" (9) because it incarnates Africa's resistance to colonial values. Human beings are constituted by their experiences; therefore, what makes the narrator an African is not just his name, but also "the circumstances he has been born into, circumstances that are part of him" (9). "Tinyarei" is thus a repudiation of Western thought and an affirmation of African cosmological perspectives.

\section{The Lived African Experience versus "Satellite" Knowledge}

In the same vein, the chapter "The light of Western civilization" which, in its very title, comes across as mocking Western modernity, seeks to affirm and celebrate African knowledge systems that were castigated as primitive by the colonial enterprise. The West has always projected itself as an epitome of democratic values such as liberty, equality, and freedom of expression; however, considering its policies in Africa, particularly the fact that Western countries continue to facilitate political instability in some African countries, this standpoint becomes questionable. The so-called light of Western civilization, which was meant to redeem Africa from darkness, is ironically responsible for war and political instability. As mentioned, Gomo's poetic novel challenges the double standards and hypocrisy of the West, particularly 
in relation to its dealings with former colonies. The soldier-narrator's Afroradical position emanates from his personal experiences of war in the DRC. Therefore, his ideological convictions are not necessarily imposed on the text; instead they emerge organically from his interpretation of his experiences. Mashingaidze Gomo himself, like his soldier-narrator, was a helicopter technician and gunner in the Zimbabwean Defence Forces and in the DRC war (Whittaker 2010). "While Afropolitans talk and talk about what it means to be young, cool, and African" (Dabiri 2014:106), Gomo focuses on the crude realities of a specific part of Africa, the DRC, which he knows from personal experience.

"The light of Western civilization" begins as an innocent narration of routine events in the life of a soldier on the battlefront, which involve servicing "aircraft and weapons" (38). However, these mundane activities are only a platform from which the narrator launches his analysis of postcolonial African politics. The heat of the equatorial region makes the narrator realize that there is a world of difference between theory (what he learned at school) and practice (what he experiences on the battlefront). What he learned in his geography lessons at high school did not prepare him at all for the realities of the equatorial weather. This gap between practice and theory opens up a debate on the nature of education in Africa. The point is that the African experience has for a long time been theorized and represented by "tourist" intellectuals who lack practical experience of the realities on the ground. There is a world of difference between lived experience and satellite knowledge, or knowledge acquired through secondary sources. Since Gomo is a soldier himself, it is not surprising that he privileges the voice of the man on the spot above that of the tourist intellectual. The theoretical approach to knowledge acquisition is represented by the geography teacher who teaches about an equatorial climate that he has never experienced:

Yet it had been nice to be young and naïve in high school

Sitting there, listening to talk about exotic lands even the teachers themselves had never seen and ideas so alien it was sometimes difficult to relate to them

The geography, history, literature, religious studies ...

Much of it sometimes so astonishingly, so catastrophically irrelevant to our destitution that there are many good people today . . . unbelievably many good African people walking the streets of African capitals today, jobless and classified illiterate because they failed something absolutely irrelevant to the African experience (38)

The narrator does not necessarily condemn or dismiss academic knowledge as useless, for he says "it was nice to be young and naïve." However, he realizes that experiential knowledge is more reliable than book knowledge. Even the geography teacher did not realize that his geography was far different from reality. However, the narrator is not particularly concerned about 
retelling his high school experience; the experience is only an entry point for him to interrogate larger issues in relation to the kind of education Africa needs going forward. Thus the narrative moves from mundane issues such as servicing weapons to more complex issues such as the content of education in African schools. The excerpt above makes a point that African education needs to focus on the African experience so as to prepare students for relevant social, political, and economic issues in Africa. If education cannot prepare the learner for the real world (as exemplified by the soldiernarrator's geography lessons in high school), then it is irrelevant and unfit for its purpose.

The narrator's high school curriculum is largely Eurocentric, as it comprises "the great ideals of the French revolution" and "the rise of European nationalism" (38), which are clearly irrelevant to the African context. Western education, as represented in this work, is not only irrelevant, but also fraught with unexplained contradictions that make it confusing to the learner. For example, the "famous white men of the cloth," who ideally were supposed to bring salvation to Africa, were also responsible for facilitating "dispossession and forced labour of poor African people" (39). Similarly, the West continues to claim to be a custodian of democracy and the rule of law while it supports "minority apartheid governments that deny African people the right to vote and chart their own destiny" (39). The point here is that Eurocentric education has an imperialist agenda. Its ultimate goal is to keep Africans psychologically dependent by portraying Europe as the center of knowledge around which everything else revolves. Even works of writers such as Shakespeare promote a Eurocentric world view that represents Africa as a chaotic continent that can only experience order through intervention from the West. The narrator makes reference to the Elizabethan view of a "God-created cosmos in which order was imposed on chaos" (39), a cosmological view that was used during colonialism to justify conquest. The same world view continues to be used in the neocolonial era to justify the West's interference in African affairs. Since Western education is divorced from, and has no relevance to, the African experience, those who acquire it also tend to be irrelevant to the environment in which they are supposed to operate. The narrator suggests that the objective of Eurocentric education is to foster Western capitalist values, such as individualism, which are at variance with African philosophies of life, such as ubuntu (human interdependence). The narrator recreates and retells the history of colonialism, showing that the colonial agenda was designed to ensnare Africans through a Eurocentric education system that did not resonate with the African experience. The narrator observes that the dialectical contradictions within Western epistemology produced anticolonial resistance because it could not explain the mismatch between education as theory in the classroom and the practical experience of Africans in the African milieu. "And contrary to imperialist design, some of the educated / elite sampled their experience and compared notes with / the European man's experience / And the results led to war" (40). 
Although this is a somewhat reductionist (re)presentation of the events that led to anticolonial resistance in Africa, the point is that Western education helped educated Africans to see the ultimate objectives of the colonial enterprise. The anticolonial wars that were fought throughout Africa exposed the hypocrisy of the so-called civilizing and democratizing agenda because, contrary to what they professed to stand for, Europeans fought "with a satanic resolve to preserve / apartheid minority rule that did not extend sanctity of life to the African people" (40). Contrary to popular views that associate soldiers with ignorance, the soldier-narrator in this poem insists that "today's African soldier is a man who has studied the concepts for which he fights" (40). Since the soldier-narrator understands the issues for which he risks his life on the battlefield, he is, perhaps, in a better position to interpret the problems facing the African continent. As a poet and a soldier, the narrator is endowed with double vision that enables him to have a balanced view. The narrative seeks to move the center not only from its supposed residence in the West, but also from the minds of professional historians and intellectuals to ordinary citizens (soldiers, villagers, prisoners, etc.) who are the makers of history. The educated African soldier is no longer a stooge because he

\footnotetext{
... knows that Zimbabwe's history has to be told by the spirits of the First Chimurenga who know that no lessons about tolerance can be learnt from invading imperialists who beheaded African people for resisting dispossession and forced labour...

He knows that African history has to be written by the guerrilla and the detainee who fought white people's prejudice
}

The guerrilla who was where it all happened (40-41)

This assertion is probably premised on the fact that African history has over the years been written, first by European colonizers, whose African history is nothing but the history of Europeans in Africa, and second, by nationalist historians, who also reduced African history to the history of great men who "brought" independence. The soldier-narrator is of the opinion that history should be told by those who lived it. Europe's representation of the African experience is bound to be biased because of Europe's economic interests in Africa. The guerrilla and the detainee are seen as better qualified to write the history of Africa because they have first-hand experience. A Fine Madness thus seems to advocate a bottom-up approach to "nationwriting" which seeks to democratize the discursive center. The narrator identifies "spirits of the First Chimurenga," "descendants of the beheaded," "the guerrilla and the detainee," "villagers," "African armies," "African pilots and gunners," and "first hand victims of neo-colonialism" (41-42) as the right groups to narrate the history of Africa. A common thread among these groups is that they all have direct contact with historical realities as they unfold. "Spirit mediums" know African history because they 
inspired liberation struggles across Africa; "the descendants of the beheaded" have a unique experience of the trauma of death by beheading; and "villagers" know about the brutalities of the colonial experience and the wars of liberation because oftentimes they were eye witnesses. "Victims of neo-colonialism" have a particular understanding of conditions that derive from their unique lived experiences. They know that "the European community still grudgingly retains a savagery that belongs to the darkest side of the beast world [,] . . . a savagery with which to deal with African people" (42). This savagery, the narrator suggests, is likely to be missed by a historian without firsthand experience.

The narrator also makes an interesting point that "African history should actually be designed [my emphasis] and not left to providence and chance" (42). This view implies that African historians should construct a particular version of African history that is informed by the African experience and indigenous modes of narration. It is understandable to say that African history should not be left to "providence and chance" so as to protect it from Eurocentric distortions. However, the idea of "designing" history has connotations of institutionalized bias. Perhaps the question is: who exactly would be tasked with this delicate task of "designing" history and to what extent is he or she likely to be objective? The narrator feels that it is necessary to deliberately paint a positive image of Africa in order to offset distortions promoted by the Western imagination. African history should be authored by "a new breed of Judges . . who know no other law except the old Law of Moses" (42). Although scholars such as Mbembe (2002) would likely not agree with this approach on the basis that it repeats the binary logic of colonial discourses, a radical approach may be necessary in a situation in which the erstwhile colonizer deliberately and unapologetically keeps the former colonized in a state of eternal poverty. This is perhaps the reason that Fanon advised that the issue of wealth redistribution would have to be addressed, no matter how devastating the consequences. In light of the skewed justice system of colonial regimes, the narrator feels that equality can only be achieved through a "Mosaic justice that should not allow invading land grabbers to hold onto even a square millimetre of stolen land" (42-43). The narrator recommends this approach (although it may seem retrogressive) because the former colonizer is "not willing to let go of the enslaved African" (43). If the world has been made binary on the basis of centuries of stolen labor, then perhaps the only method of unification is payment for what has been stolen (see Bohrer 2015).

The narrator also makes an important distinction between writing / retelling history and making history. Retelling history should be undertaken by those with first-hand experience, while history should be made by Afrocentric citizens such as judges who see it as their responsibility to address injustices of the past, "reviewing all murders and correcting social and economic injustices without regret or apology" (43). Apart from judges who, according to the narrator, have a responsibility to balance the scales of historical injustice, history is also made through Afrocentric constitutions 
"that do not accord human rights to oppressors who do not have respect for black human rights" (43). While it is generally assumed, particularly by Western financial institutions such as the World Bank and the IMF, that Africa needs strong institutions more than it needs strong men, the narrator maintains that African history must be made by "hard old men wise enough to know that strength is not always in color, numbers or sophistication but mostly in being right" (43). Perhaps the narrator has in mind nationalists such as Robert Mugabe who, in spite of strong opposition from the West, has been adamant about his policy of land redistribution without compensation. In view of the foregoing, one can argue that "the light of Western civilization" is a discursive attempt to reverse the colonial historical trajectory by rewriting African history from the margins.

This preoccupation with redressing colonial and neocolonial distortions is further developed in the chapter "Kufa kunesu machewe (Death is with us for real)." The chapter starts as a simple narration of soldiers' daily routines on the battlefront, which involve sharing stories of war experiences, reminiscing over past successes, and narrating tales of hair-raising near-death experiences: "And they talked wistfully / about life and about mortality ... and they talked wistfully as men who have walked the company of death" (100). In these opening lines, the narrative creates a picture of unique life experiences that only soldiers are familiar with. The experiences that the soldiers share-for example, "about a corporal and a private who had once saved the day" — cannot be fully captured by intellectuals with no hands-on experience. While "The light of Western civilization" starts with soldiers servicing their aircraft and weapons, "Kufa kunesu machewe" starts with a moment of musical recreation on the battlefront, a moment that affords war-weary soldiers an opportunity to forget the perpetual presence of death and savor the soothing sounds of music. While the music is a necessary pastime and an antidote for loneliness, it is also a vehicle through which the narrator interrogates the war situation. The mbira music that the soldiers play is usually played during traditional ceremonies as a means to communicate with the ancestors. Perhaps this explains why, when "the commando" and "one of the men on transit" begin to play the instrument, the sound that ensues retraces the history of colonialism (100). The "man in transit," playing the lead tune, represents the colonized, while the tall commando, providing the bass notes, represents the colonizer. The "man in transit" is characterized as "a stubbornlooking, wiry traditional man with strong hands," a description that evokes African people's resilience and refusal to bow down to colonial subjugation. "And the tune of his choice was a wistful one .. . / a migration of sound from the darkest recesses of the race psych . . . tentatively descending the broken hills of African experience into the valley of neo-colonial conflict below ... / The African Armageddon” (101).

The "darkest recesses of the race psych" probably refers to the memories of black people which constitute African history. The line "broken hills of African experience" evokes African ways of life that were eroded 
by colonialism. Evidently, there is a direct correlation between the "broken hills of African experience" and "the valley of neo-colonial conflict," as if to imply that the current state of affairs in Africa cannot be separated from the history of colonialism. The narrator equates Africa's neocolonial experience with the biblical war of the end of the world, the "Armageddon," a metaphor that foregrounds the extent of the devastation caused by neocolonial conflict in Africa. The tall commando, symbolic of the colonizer, stalks the man on transit "with evil intentions" (101) just as the colonizers hunted down and jailed African revolutionaries.

And he kept to the shadows waiting for an opportune moment to pounce And in the valley of conflict, he sprung a rhythmic ambush

And his bass strand was a bully that rumbled all over the tentative lead tune...

And the tentative tune was resilient and would not fall

And it put up a surprisingly tough fight (101)

Musical and war imagery are used here to interrogate the history of colonialism and the current neocolonial situation in Africa. The bass sound (the imperialist) always waits for the right moment to pounce on its victim (the lead tune / the colonized). On the other hand, the colonized, in spite of their inferior economic and military position, continue to resist the machinations of the colonizer. The poet also uses military imagery (for example "rhythmic ambush") to portray the intentions of the imperialist (the bass sound). The imperialist is a bully who stalks weak nations for purposes of exploitation, just as the bass strand "rumbles all over the tentative lead tune." The lonely battle waged by the lead tune (the weak African nations) resembles that of a "lone guerrilla drawing strength from solitude" because it cannot get help from the international community. Through this anecdotal narrative, the narrator interrogates the predicament of African countries such as the DRC, whose efforts to get international intervention in their domestic conflicts are stalled by the fact that the international community is controlled by superpowers with imperialist motives. Therefore, when African countries that are faced with internal strife ask for help, the international community cannot intervene because it is "ruled by the bully and the most it could do for fear of victimization [is] to simply / say that what [is] being done [is] wrong" (101). Although it is not explicitly stated who the bully is, one can speculate that the bully is probably the United States, the superpower that remotely controls foreign policies of many countries the world over. It is common today for countries in the West to simply condemn atrocities without doing anything practical. Like the previous passage, this passage emphasizes the importance of experiential knowledge as opposed to book knowledge, especially in relation to writing about and interpreting African affairs. "And I thought that to understand mbira, one needs to have grown up with the music / to have had it genetically handed over / to have had it nurtured into one's formative years" (102) (my emphasis). 
The narrator is talking about not only cognitively understanding mbira music, but also appreciating the context in which this music is played. Growing up with the music and figuratively having it ingrained in one's genetic composition is a form of conceptual centeredness that allows one to see the world from a particular perspective. This obviously painstaking process of "growing up" with the music and having it "genetically" imprinted and "nurtured" into one's formative years takes time. Hence it requires one to physically inhabit a certain place (in this case, Africa) and go through particular context-specific experiences (colonialism/ neocolonialism). Again, the narrator highlights the contextual nature of knowledge and the importance of understanding context in order to appreciate a worldview. In the postcolonial context in which this narrative is situated, this entails moving the center (epistemologically) from its assumed residence in the West and resituating it in a multiplicity of centers all over the world (Ngũgĩ 1997). The narrator is also aware that local experiences, although unique, are enriched through exposure to other forms of knowledge. Understanding mbira (which can also be construed as understanding the African experience) requires not only a deep understanding of the African context, but also

To have gone away from it in pursuit of knowledge and another life

To have tasted the emptiness and meaninglessness of sophistication

And then, from that projection, to be dogged by nostalgia for things past

Nostalgia for things in the blood

To revisit the past and appreciate its values from an elevated view (102)

To go away and "taste the emptiness and meaninglessness of sophistication" suggests a process of exposing oneself to the values of the outside world in order to make an informed judgment. Exposure does not only help the narrator appreciate "things in the blood" (his roots) but also elevates him to a superior level of consciousness from which he can see the world objectively. A Fine Madness constantly reiterates the idea that life experiences have the capacity to take one to a higher level of consciousness. The notion of madness, as it is represented in this text, is not a state of mental dysfunction but an elevated state of being from which one can look down and see the world differently. This madness is fine, because it is a state of equilibrium that enables one to understand and appreciate rather than judge and condemn the unfamiliar. It is madness that "takes part in the measures of reason and in the labor of truth," that "utters truth and falsehood" (Foucault 1988:14).

In the chapters "Tinyarei" and "Divine abstraction" this state of being is physically reconstituted as Boende, a place where the narrator experiences the loneliness and pain of war. It is from this place that he gets inspiration to think through Africa's postcolonial experience and the role of the former colonial masters in the mayhem. Boende gives the narrator a vantage point from which to see through the double standard of the West. It is at Boende, 
the place of organic communion with the realities of war, that the soldiernarrator begins to appreciate the world in its epistemological diversity. Boende is actually a symbol of intellectual maturity, for it is at Boende that the narrator comes face to face with the vanity of war, pain, and life itself; it is a place where the soldier-narrator's philosophical journey comes full circle. This is clearly exemplified by the opening lines of the chapter "Divine abstraction":

At Boende, I looked into the abstract beauty of creation and saw that the universe is alive

I saw that nature is the same activity replicated on different levels of a universal hierarchy, from the micro-world of amoeba, to the celestial explosions of the universe giving birth to new galaxies

It is love, it is hate, it is restlessness and it is conflict

I saw that nature is beautifully mad and that its madness surpasses all the madness of mankind rolled into one (12)

Here the narrator comes to a realization that the universe is an ecosystem and everything depends on everything else. The "micro-world of the amoeba," though small and seemingly insignificant, is part of the "abstract beauty of creation." The lesson that the narrator learns from this moment of intellectual illumination is that nothing in the universe can stand alone. It is the violence of the equatorial storm that brings life, "because the rainstorm was water / And water was life / A life that burst onto the land with death in its wake / A paradox?" (15).

Boende is not only a place of heightened consciousness from which the narrator revisits the past and appreciates its values, but also a place of humility, where the narrator comes to terms with his inadequacies as a human being in a complex world. Similarly, the chapter "Kufa kunesu machewe" not only addresses Africa's postcolonial challenges but also explores alternative ways of accessing knowledge in a complex and diverse world. Mbira music represents a medium of accessing knowledge. It is through mbira music that the narrator begins to communicate with a world beyond the physical realm: "And the good music transcended my mind into memory lane / A solitary lane one walks all alone even when in the physical company of others" (102). Music is a medium that allows him to navigate memories and reconstruct the past. However, this past is constructed imaginatively through the power of music. Mbira music, in this poem, has the ability to evoke past experiences and bring "yesterday" into the present. It is through listening to the mystic sounds of mbira music that the narrator manages to relieve forgotten histories and traditions of his people:

And I remembered in another time and place ...

A story about trial and conviction in the village court

And a woman had danced ... possessed by an ancient spirit of the land A time traveller from the mystic beginnings of the clan, enjoying a moment of respite in the modern world (102-103) 
This story of "a woman possessed by an ancient spirit of the land" is not necessarily real, but it is also not a figment of the narrator's imagination. It is a mystical reconstruction of a lived past as evoked by the mbira music. Once the narrator has attained this elevated consciousness, he is able to see beyond the physical. This woman represents an African indigenous world that has been eroded by colonialism and replaced by Western modernity. Members of the new generation, born out of the colonial experience, cannot recognize this world because they are "possessed by the rouged deities of Western cultures and the meaninglessness of their so-called sophistication" (103). The idea that one can get "possessed" by Western deities is actually a subversion of colonial theology that associated African cultural practices with demons and represented "spiritual possession" as a pagan experience. The narrator, by contrast, suggests that Westernized Africans are actually possessed by Western deities-an idea that resonates with Afropolitans' obsession with the metropolis. Through the memories evoked by the mbira music, the narrator is able to get a glimpse of an African world of yesteryear.

And Chief Nyandoro was being inaugurated

And armed traditional men were dancing around Tinyarei

And I was asking my grandmother kuti, "Who are these people?"

And she was saying, "These are mediums of heroes of the First Chimurenga.

No heroes of like status have walked this land since!" (103)

Against the backdrop of global cultural "mutts," mbira music becomes a vehicle through which African heroes can be (re)membered. The woman "from the mystic beginnings of the clan" (103), who has been resurrected by the sounds of mbira, sings a song that laments the experiences of African people:

Kufa kunesu machewe [Death is with us for real]

Ndakanga ndabaiwa [I almost got murdered]

Kunoda vadzimu kufa kwangu [My death requires ancestral authority] (103)

This song captures three different epochs of the colonial encounter: conquest, subjugation (exploitation), and resistance. By singing this song, the woman reminds us not only of the pain of colonial exploitation, but also of the current "neoliberal" conditions that keep Africa on its death bed. Parry (1994) has argued that the past should be remembered not for purposes of promoting victimhood, but for purposes of avoiding mistakes of the past. The problem in Africa today is not necessarily slavery and colonialism, but rather the legacies they left behind, which continue to cast a long shadow on the lives of African people. For most Africans who wish to break out of the long shadow of these legacies, doing so is not as easy as denying a victim identity, as Mbembe (2007) implies, or embracing a colorless identity, as Selasi (2015) recommends. Although apartheid is legally defunct, Dabiri laments that "there is no immigration policy anywhere in the Western world 
that welcomes Africans, while a major bias against African global mobility abounds in international media" (2016:106). What does this mean for Africans or Afropolitans in the new global order? Former victims of slavery and colonialism do not need to continue lamenting their victimhood, but they should not be lulled to sleep by the success story of a few privileged Africans. The line "kunoda vadzimu kufa kwangu" (my death requires ancestral authority) is not only a defiant statement of resistance to a system that spells death for Africans, but also an affirmation of the singer's centeredness. It is not enough to say we are not victims; we need to go further and ask what that actually means for the majority of Africans who continue to be looked upon and treated as the "other" in the Western imagination, who continue to be denied free mobility in the so-called global village. Perhaps this is the reason that the Barbadian-Nigerian author Yewande Omotosu declared in response to Selasi's call for an Afropolitan identity, "I am not an Afropolitan, I am of the continent" (quoted in Fasselt 2015: 235).

\section{Conclusion}

What direction should African modes of self-writing take in the context of the neoliberal global order? How should Africans narrate themselves? These are questions that have attracted a great deal of controversy in recent years. Scholars such as Achille Mbembe (2002, 2007) and Kwame Anthony Appiah (2000) insist that Africans should not continue to narrate themselves as victims of slavery and colonialism. These scholars argue that the reverse discourse of resistance is retrogressive because it repeats the same binary logic of colonizer/colonized, oppressor/oppressor, black/white, which is associated with colonial discourse. Mbembe (2002) traces the origins of nativism to colonial discourses that justified slavery and colonialism by emphasizing the particularity and/or inferiority of the black race. In place of nativist identities, Mbembe (2007) and Chielozona Eze (2014) advocate Afropolitanism as a new, alternative way of styling African identity. This new way of writing African identity has been questioned, however, by a number of scholars such as Emma Dabiri (2016) and Binyavanga Wainaina (2013). The problem with Afropolitanism, at least as it is represented by Taiye Selasi (2015), the writer who is credited with coining the term, is that it subsumes the majority of Africans under the success stories of a privileged few. The idea of an "Afropolitan" is that of an African who is mobile, transnational, and not confined to a geographical place. However, this category cannot represent the majority of Africans who continue to be denied any kind of mobility in the neoliberal global order. This article has argued that African narratives cannot afford to stand aloof and ignore the social, economic, and political upheavals that continue to haunt the continent. In addition, Africans need not always measure themselves against the West, as the notion of Afropolitan (an African of the metropolis) implies. The novelist Chimamanda Ngozi Adichie speaks about becoming less interested in the way the West sees Africa and increasingly concerned by how Africa sees itself (quoted in Dabiri 2016:107). 
Mashingaidze Gomo's A Fine Madness, as this article has demonstrated, is a counterdiscursive text that seeks to discount narratives that represent Africa as an appendage of the West. It is an overtly ideological "narrative which counters anti-state discourses that contest the state's sites of political legitimacy in Africa" (Nyambi 2015:2). In defense of what he perceives as a beleaguered African continent, Gomo launches a radical rewriting of African history for the purposes of reeducating Africans who seemingly have been brainwashed and are being led astray by foreign-backed opposition parties and rebel groups. The educating function of Gomo's work is assisted by the fact that the story is told by a man who has been in the trenches fighting for the African cause. Oftentimes, the African experience is interpreted by intellectuals, who, in spite of their academic accolades, lack the first-hand experience that a soldier brings to the table. It is undeniable, however, that A Fine Madness draws extensively from the political narratives of the Mugabe regime, a fact that could compromise its objectivity. However, one cannot also deny that in spite of its ideological leanings, the text remains poetically compelling, particularly in terms of the way it imaginatively recreates the African colonial/neocolonial experience. The poetnarrator's double function as soldier and poet enriches and complicates his vision of the neocolonial challenges facing Africa.

\section{References}

Achebe, Chinua. 1990 (1988). Hopes and Impediments: Selected Essays. New York: Anchor Books.

Appiah, Kwame Anthony. 2000. "New Literature, New Theory?” Matatu 7: 57-89.

Chinunda, Emmanuel. D. 2014. Grappling with Change in Africa: The Dream of Prosperity Using African Wisdom. London: Author House

Dabiri, Emma. 2016. "Why I Am (Still) Not an Afropolitan." Journal of African Cultural Studies 28 (1): 104-8.

Eze, Chielozona. 2014. "Rethinking African Culture and Identity: The Afropolitan Model." Journal of African Cultural Studies 26 (2): 234-47.

Fanon, Frantz. 2004. The Wretched of the Earth. Translated by Richard Philcox. New York: Grove Press.

Fasselt, Rebecca. 2015. "I'm Not Afropolitan — I'm of the Continent': A Conversation with Yewande Omotoso." The Journal of Commonwealth Literature 50 (2): 231-46.

Foucault, Michel. 1988. Madness and Civilization: A History of Insanity in the Age of Reason. Translated by Richard Howard. New York: Vintage.

Gomo, Mashingaidze. 2010. A Fine Madness. Oxfordshire: Ayebia Clarke.

Gore, Marcia. 2013. "Know Your Author: Mashingaidze Gomo." The Herald, December 2.

Lara, Maria Pia. 1998. Moral Textures: Feminist Narratives in the Public Sphere. Berkeley: University of California Press.

Makombe, Rodwell. 2014. "Cultural Nationalism in Mashingaidze Gomo's A Fine Madness." Tydskrif vir Letterkunde 51 (2): 82-93.

Mbembe, Achille. 1992. "Provisional Notes on the Postcolony." Africa: Journal of the International African Institute 62 (1): 3-37.

—. 2002. "African Modes of Self-Writing." Public Culture 14 (1): 239-73. 
2007. Africa Remix: Contemporary Art of a Continent. Johannesburg: Jacana Media. Mtizira-Nondo, Nyaradzo. 2008. The Chimurenga Protocol. Harare: Botshelo Publishing. Ndlovu-Gatsheni, Sabelo J. 2007. "Tracking the Historical Roots of Post-Apartheid Citizenship Problems: The Native Club, Restless Natives, Panicking Settlers and the Politics of Nativism in South Africa." ASC Working Paper. Leiden: African Studies Centre.

- 2009. "Africa for Africans or Africa for 'Natives' Only? 'New Nationalism' and Nativism in Zimbabwe and South Africa." Africa Spectrum 44 (1): 61-78.

Ngũgĩ wa Thiong'o. 1981. Writers in Politics. London: Heinemann.

Nyambi, Oliver. 2011. "Some Notes on Ways to Read Zimbabwean Literature of the 'Crisis." Writing Africa 7 (1): 1-12.

- 2015. "Writing Back to Colonialism, Again: The Novel The Chimurenga Protocol and the New Resistance Literary Culture in Post-2000 Zimbabwe." Literator 36 (1): 1-9.

_. 2016. “'The Lion Has Learnt to Speak?’ The Novel A Fine Madness and Third Chimurenga Counter-Discourse in Contemporary Zimbabwe." Journal of Black Studies 47 (3): 217-34.

Parry, Benita. 1994. "Resistance Theory, Theorising Resistance or Two Cheers to Nativism." In Colonial Discourse/Postcolonial Theory, edited by Francis Barker, Peter Hulme, and Margaret Iverson, 172-96. Manchester, U.K.: Manchester University Press.

Santana, Stephanie Bosch. 2013. "Exorcizing Afropolitanism: Binyavanga Wainaina Explains Why 'I Am a Pan-Africanist, Not an Afropolitan' at ASAUK 2012.” https://africainwords.com.

Selasi, Taiye. 2015. "Bye-Bye Barbar." LIP Magazine. http://thelip.robertsharp.co.uk. Wainaina, Binyavanga. 2006. "How to Write about Africa." Granta 92: The View from Africa. http://granta.com.

Whittaker, Peter. 2010. Review of A Fine Madness. New Internationalist, October. https://newint.org.

Ziwira, Elliot. 2015. "Freedom Without Ownership a 'Fine Madness'?”www.herald. co.zW.

\section{Note}

1. The term "self-narration" is used interchangeably with "self-writing" in this article to refer to the process of telling one's own story. 